\title{
Concentration of mercury in muscles of predatory and non-predatory fish from lake Pluszne (Poland)
}

\author{
Joanna Łuczyńska ${ }^{1}$, Marek Jan Łuczyński², \\ Beata Paszczyk ${ }^{1}$, Elżbieta Tońska ${ }^{1}$ \\ ${ }^{1}$ Department of Commodities and Food Analysis, \\ University of Warmia and Mazury in Olsztyn, 10-726 Olsztyn, Poland \\ ${ }^{2}$ Department of Ichthyology, \\ Stanisław Sakowicz Inland Fisheries Institute, 10-719 Olsztyn, Poland \\ jlucz@uwm.edu.pl
}

Received: October 12, 2015 Accepted: February 19, 2016

\begin{abstract}
Introduction: The study examined the concentration of total mercury and correlation coefficients between fish size or FCF (condition factor) and the content of $\mathrm{Hg}$ in muscle tissue of six freshwater fish: bream (Abramis brama L.), roach (Rutilus rutilus L.), whitefish (Coregonus lavaretus L.), vendace (Coregonus albula L.), perch (Perca fluviatilis L.), and pike (Esox lucius L.). Material and Methods: The fish were caught from the Lake Pluszne located in the Olsztyn Lake District (Poland). Mercury was analysed by atomic absorption spectrometry using Milestone DMA- 80 (with dual-cell). Results: The content of the element in the muscles of the examined fish was as follows: pike $(0.197 \mathrm{mg} / \mathrm{kg}) \approx$ perch $(0.173 \mathrm{mg} / \mathrm{kg})>$ vendace $(0.114 \mathrm{mg} / \mathrm{kg}) \approx$ roach $(0.095 \mathrm{mg} / \mathrm{kg})$ and roach $\approx$ whitefish $(0.065 \mathrm{mg} / \mathrm{kg})$, and whitefish $\approx \operatorname{bream}(0.042 \mathrm{mg} / \mathrm{kg})(\mathrm{p} \leq 0.05)$. In all cases, the content of mercury correlated positively with the body weight and total length of the fish. Only the correlation coefficients between mercury concentration and weight or length of bream were slightly higher $(0.979$ and 0.977 respectively, $\mathrm{p} \leq 0.001)$. The length and weight relationship of the fish was also determined. Conclusion: The results showed that the levels of mercury were lower than the maximum acceptable limit established by the Commission Regulation (EC) No 629/2008 of 2 July 2008. Thus, they are safe from consumer health point of view.
\end{abstract}

Keywords: freshwater fish, mercury, muscles, factor condition, correlation.

\section{Introduction}

The amount of metal absorbed by fish is determined by various aquatic organisms (plants, phytoplankton, zooplankton, snails, insect larvae, fish-fry, phytophagous, turbellarians, nematodes, mites, fish feeding on plankton, and predatory fish) belonging to food chains of the aquatic environment. Kehrig et al. (10) showed the transfer of total mercury from the lower trophic level-prey to the top-level predator; it means that the content of mercury increased with the advance in food chain. Atmospheric deposition, domestic sewage, and industrial wastewater are the main sources of waterborne metals, including mercury $(4,9)$. Dissolved forms of mercury enter the body through respiratory epithelium of the gills and gill cavities, as well as through the olfactory epithelium and skin. Bound forms of mercury and those absorbed by feed surfaces infiltrate through the alimentary canal (24). Mercury is a particularly dangerous food contaminant and does not perform any biological functions, in neither human nor animal organisms. A high concentration of mercury in fatty tissue of fish may diminish the beneficial effects of its n-3 fatty acids (7). Fish can be seen as an effective indicator of food and aquatic environment contamination with some elements and compounds. Boyd (3) reported that heavy metals in freshwater habitats can modify chemical communications between individuals and can affect ecological relationship both intra- and interspecies. Jezierska and Witeska (9) reported that the content of mercury in fish is affected by many factors, such as fish species, body weight, total length, body condition. Consequently, the aim of the present study was to determine the dependence between the size (body 
weight and total length) or condition factor and the concentration of mercury in the muscles of freshwater fish, and to evaluate the interspecies differences in the content of this metal. As a continuation of previous studies, this research also intends to establish whether there has been an increase in fish mercury pollution.

\section{Material and Methods}

Bream (Abramis brama L.), roach (Rutilus rutilus L.), whitefish (Coregonus lavaretus L.), vendace (Coregonus albula L.), perch (Perca fluviatilis L.), and pike (Esox lucius L.) were caught from the lake Pluszne located in the Olsztyn Lake District (Poland). Sample fish were transferred to the laboratory on the same day, where the body weight $( \pm 0.1 \mathrm{~g})$ and total length $( \pm 0.1 \mathrm{~cm})$ of each fish were measured (Table 1$)$. The muscles were taken from the dorsal section, and then they were mixed and stored in polypropylene bags at $-30^{\circ} \mathrm{C}$ prior to analysis. Each sample was prepared from the organs taken from one specimen.

Duplicate muscle samples of up to $270 \mathrm{mg}$ $( \pm 0.0001 \mathrm{~g})$ were weighed in a quartz boat and analysed according to the Application Book (only for Direct Mercury Analyzer), included with the software (DMA 80 PC/T640/1640rev.o2 A or higher). The total mercury concentration was processed with atomic absorption spectrometry thermal decomposition using Milestone DMA-80 (with dual-cell). Parameters of ramp for drying and decomposition (temperature/time respectively) were as follows: max. start temperature $-200^{\circ} \mathrm{C}$ for $60 \mathrm{~s}$, drying $-160^{\circ} \mathrm{C}$ for $60 \mathrm{~s}$; decomposition (burned in the oxygen flow) $-650^{\circ} \mathrm{C}$ for $60 \mathrm{~s}$. The absorption wavelength was $253.65 \mathrm{~nm}$ (detection limit - $0.005 \mathrm{ng}$ $\mathrm{Hg}$ ) and the detector comprised UV enhanced photodiodes. The analysis method was tested by measuring the elements in reference material: BCR CRM 422 (muscles of cod Gadus morhua (L.)). The percentage recovery rate was $100.2 \%(n=4)$.

The data were calculated using the one-way analysis of variance ANOVA (Duncan's test) (STATISTICA 10) to evaluate interspecific differences in mercury content in fish muscles. Levene's test for homogeneity of variance showed that variances in different groups were homogenous. Differences at $\mathrm{p}<0.05$ were found significant. The length-weight relationship and the correlation coefficients between the content of mercury and condition factor, body weight and total length of fish were calculated using a STATISTICA 10 programme.

The condition of fish was calculated with Fulton's condition factor $(\mathrm{FCF})$ : $\mathrm{FCF}=100 * \mathrm{~W} / \mathrm{L}^{3}$, where: $\mathrm{W}$ - total body weight of fish (g), L - total length of fish (cm).

Total length-weight relationship of each fish was determined by the formula: $\mathrm{W}=\mathrm{a} \mathrm{L}^{\mathrm{b}}$ and expressed in its logarithmic form of linear equation as: $\log W=\log a+$ b Log L, where $\log \mathrm{W}-(\mathrm{y}) ; \log \mathrm{L}-(\mathrm{x})$, a (intercept of the line on $y$ ) and $b$ (slope of the regression line) were constants.

\section{Results}

Table 1 shows the content of total mercury in the muscles of the fish studied. Differences in mercury concentration in the muscle tissue of predatory fish (pike and perch) and non-predatory fish (roach, bream, vendace, and whitefish) were observed $(p \leq 0.05)$. The muscles of pike and perch contained more mercury (0.197 and $0.173 \mathrm{mg} / \mathrm{kg}$ respectively) than other fish: roach - $0.095 \mathrm{mg} / \mathrm{kg}$, bream - $0.042 \mathrm{mg} / \mathrm{kg}$, vendace $0.114 \mathrm{mg} / \mathrm{kg}$, and whitefish $-0.065 \mathrm{mg} / \mathrm{kg}$. There were no significant differences between the content of mercury in the muscles of pike and the muscle tissue of perch $(p>0.05)$. Similar differences between the following groups: roach and vendace; roach and whitefish; whitefish and bream, were not statistically significant $(\mathrm{p}>0.05)$.

The concentration of total mercury in muscles was positively correlated with body weight and total length of the fish (Table 2). The correlation between the body weight and total length of bream and total mercury content was the highest $(r=0.979$ and $0.977, p=0.0000$ respectively). The correlation coefficients also indicated that there was a strong significant positive relationship $(p=0.002)$ between mercury level in the muscle of perch and body weight $(r=0.962)$ and total length $(\mathrm{r}=0.963)$. The next strongest positive correlation was observed between total mercury content in muscles of pike or whitefish and body weight $(r=0.946, p=0.004$, and $\mathrm{r}=0.961, \mathrm{p}=0.002$, respectively) and total length $(\mathrm{r}=0.945, \mathrm{p}=0.004$ and $\mathrm{r}=0.957, \mathrm{p}=0.003$, respectively). In the other fish species the correlation coefficients between total mercury concentration and fish body weight were not significant: $r=0.323$, $\mathrm{p}=0.532$ (roach) and $\mathrm{r}=0.704, \mathrm{p}=0.119$ (vendace) or length at $r=0.717, p=0.109$ (roach) and $r=0.734$, $\mathrm{p}=0.096$ (vendace).

The content of mercury declined with a decrease in the FCF, with the exception of roach. This correlation was: $0.713, \mathrm{p}=0.031$ (bream), $0.465, \mathrm{p}=0.352$ (perch), $0.728, p=0.101$ (whitefish), 0.219, $\mathrm{p}=0.676$ (pike), and $0.359, p=0.485$ (vendace). In the case of roach, there was a negative correlation between the content of mercury and FCF $(r=-0.598, p=0.209)$.

Table 3 presents equation parameters of the total length - body weight relationship as "a" (intercept of the line on y), "b" (slope of the regression line) and relative condition factor $\left(\mathrm{W}=\mathrm{a} \mathrm{L}^{\mathrm{b}}\right)$, which was expressed as:

$$
\begin{aligned}
& \log (W)=-2.567+3.388 \log (\mathrm{L})(\text { bream }) \\
& \log (W)=0.147+1.695 \log (\mathrm{L})(\text { roach }) \\
& \log (W)=-2.331+3.175 \log (\mathrm{L})(\text { vendace }) \\
& \log (W)=-3.988+4.275 \log (\mathrm{L})(\text { whitefish }) \\
& \log (\mathrm{W})=-2.360+3.384 \log (\mathrm{L})(\text { perch }) \\
& \log (W)=-2.386+3.114 \log (\mathrm{L})(\text { pike })
\end{aligned}
$$


Table 1. Total weight, length of fish, and mean concentration of mercury ( $\mathrm{mg} / \mathrm{kg}$ wet weight) in muscles of freshwater fish

\begin{tabular}{|c|c|c|c|c|c|c|}
\hline & Bream & Roach & Vendace & Whitefish & Perch & Pike \\
\hline $\mathrm{n}$ & 9 & 6 & 6 & 6 & 6 & 6 \\
\hline $\begin{array}{l}\text { Body weight } \\
\text { (g) }\end{array}$ & $\begin{array}{l}423.6-1880.0 \\
1030.1 \pm 611.9\end{array}$ & $\begin{array}{l}411.3-542.8 \\
478.0 \pm 56.5\end{array}$ & $\begin{array}{l}56.9-131.4 \\
87.9 \pm 26.3\end{array}$ & $\begin{array}{l}275.5-592.7 \\
415.8 \pm 113.1\end{array}$ & $\begin{array}{l}159.8-559.5 \\
340.9 \pm 146.9\end{array}$ & $\begin{array}{l}743.4-1843.6 \\
1155.9 \pm 472.4\end{array}$ \\
\hline $\begin{array}{l}\text { Total length } \\
(\mathrm{cm})\end{array}$ & $\begin{array}{l}33.7-52.3 \\
42.8 \pm 7.4\end{array}$ & $\begin{array}{l}29.3-33.3 \\
31.5 \pm 1.5\end{array}$ & $\begin{array}{l}19.5-24.9 \\
22.0 \pm 2.0\end{array}$ & $\begin{array}{l}32.1-37.5 \\
34.9 \pm 2.1\end{array}$ & $\begin{array}{l}22.7-33.0 \\
27.5 \pm 3.7\end{array}$ & $\begin{array}{l}50.0-66.5 \\
55.4 \pm 7.0\end{array}$ \\
\hline Main feed & $\begin{array}{l}\text { Plankton - first } \\
\text { feed, insect larvae, } \\
\text { crustaceans, } \\
\text { oligochaets and } \\
\text { chironomids - later }\end{array}$ & $\begin{array}{l}\text { Plankton - for } \\
\text { the first two } \\
\text { years, molluscs } \\
\text { and crustaceans - } \\
\text { later }\end{array}$ & zooplankton & $\begin{array}{l}\text { Zooplankton and } \\
\text { plankton, } \\
\text { benthic feeders - } \\
\text { later }\end{array}$ & $\begin{array}{l}\text { Plankton, small } \\
\text { invertebrates - } \\
\text { fish smaller than } \\
10 \mathrm{~cm} \text {, } \\
\text { top predator - } \\
\text { large perch }\end{array}$ & $\begin{array}{l}\text { Plankton - first } \\
\text { feed, } \\
\text { top predator }\end{array}$ \\
\hline mean & $0.042 \mathrm{~d}$ & $0.095 \mathrm{bc}$ & $0.114 b$ & $0.065 \mathrm{~cd}$ & $0.173 \mathrm{a}$ & $0.197 \mathrm{a}$ \\
\hline SD & 0.030 & 0.016 & 0.032 & 0.010 & 0.062 & 0.046 \\
\hline $\min$ & 0.007 & 0.075 & 0.050 & 0.054 & 0.110 & 0.144 \\
\hline $\max$ & 0.088 & 0.111 & 0.139 & 0.081 & 0.282 & 0.275 \\
\hline median & 0.036 & 0.096 & 0.125 & 0.063 & 0.164 & 0.187 \\
\hline
\end{tabular}

$\mathrm{n}$ - number of fish; SD - standard deviation; min - minimum; max - maximum; $\mathrm{a}, \mathrm{b}, \mathrm{c}, \mathrm{d}-\mathrm{p} \leq 0.05$ between the muscles of fish species. The same letter indicates the absence of significant differences between muscles of fish studied $(\mathrm{p}>0.05)$

Table 2. Regression equations and linear correlation coefficients (r) between content of mercury (mean y) (mg/kg wet weight) in muscles of fish and body weight or total length (mean $\mathrm{x}$ )

\begin{tabular}{llllccc}
\hline Species & Body weight $(\mathrm{r})$ & $\mathrm{p}$ & Regression equations $(\mathrm{y})$ & Total length $(\mathrm{r})$ & $\mathrm{p}$ & Regression equations (y) \\
\hline $\begin{array}{l}\text { Abramis brama } \mathrm{L} \text {. } \\
\mathrm{n}=9\end{array}$ & 0.979 & 0.0000 & $0.008 \pm 4.8797 * 10^{-5} \mathrm{x}$ & 0.977 & 0.0000 & $0.1297+0.004 \mathrm{x}$ \\
$\begin{array}{l}\text { Rutilus rutilus } \mathrm{L} \text {. } \\
\mathrm{n}=6\end{array}$ & 0.323 & 0.532 & $0.0506+9.235^{*} 10^{-5} \mathrm{x}$ & 0.717 & 0.109 & $0.1484+0.0078 \mathrm{x}$ \\
$\begin{array}{l}\text { Coregonus albula } \mathrm{L} \text {. } \\
\mathrm{n}=6\end{array}$ & 0.704 & 0.119 & $0.03841+0.86 * 10^{-3} \mathrm{x}$ & 0.734 & 0.096 & $0.1430+0.01167 \mathrm{x}$ \\
$\begin{array}{l}\text { Coregonus lavaretus } \mathrm{L} \text {. } \\
\mathrm{n}=6\end{array}$ & 0.961 & 0.002 & $0.02967+0.85 * 10^{-4} \mathrm{x}$ & 0.957 & 0.003 & $0.0955+0.00460 \mathrm{x}$ \\
$\begin{array}{l}\text { Perca fluviatilis } \mathrm{L} \text {. } \\
\mathrm{n}=6\end{array}$ & 0.962 & 0.002 & $0.0348+0.0004 \mathrm{x}$ & 0.963 & 0.002 & $0.2749+0.0163 \mathrm{x}$ \\
$\begin{array}{l}\text { Esox lucius } \mathrm{L} \text {. } \\
\mathrm{n}=6\end{array}$ & 0.946 & 0.004 & $0.09084+0.92 * 10^{-4} \mathrm{x}$ & 0.945 & 0.004 & $0.1473+0.00622 \mathrm{x}$ \\
\hline
\end{tabular}

$\mathrm{n}$ - number of fish; $\mathrm{p}$ - significance levels for the correlation between the content of mercury in muscles of fish and their body weight or total length

Table 3. Equation parameters of the total length (L) - body weight (W) relationship

\begin{tabular}{|c|c|c|c|c|c|c|c|}
\hline & FCF & $\mathrm{a}$ & $\mathrm{b}$ & $\mathrm{SE}(\mathrm{b})$ & $\mathrm{R}^{2}$ & $\mathrm{p}$ & $\mathrm{W}=\mathrm{a} \mathrm{L}^{\mathrm{b}}$ \\
\hline $\begin{array}{l}\text { Abramis brama } \mathrm{L} \text {. } \\
\mathrm{n}=9\end{array}$ & 1.171 & 0.0027 & 3.388 & 0.225 & 0.970 & 0.0000 & $0.0027 \mathrm{~L}^{3.388}$ \\
\hline $\begin{array}{l}\text { Rutilus rutilus } \mathrm{L} \text {. } \\
\mathrm{n}=6\end{array}$ & 1.567 & 1.392 & 1.695 & 0.914 & 0.462 & 0.1372 & $1.392 \mathrm{~L}^{1.695}$ \\
\hline $\begin{array}{l}\text { Coregonus albula L. } \\
\mathrm{n}=6\end{array}$ & 0.804 & 0.0047 & 3.175 & 0.298 & 0.966 & 0.0004 & $0.0047 \mathrm{~L}^{3.175}$ \\
\hline $\begin{array}{l}\text { Coregonus lavaretus L. } \\
\mathrm{n}=6\end{array}$ & 0.957 & 0.0001 & 4.275 & 0.720 & 0.898 & 0.0040 & $0.0001 \mathrm{~L}^{4.275}$ \\
\hline $\begin{array}{l}\text { Perca fluviatilis } \mathrm{L} \text {. } \\
\mathrm{n}=6\end{array}$ & 1.556 & 0.0044 & 3.384 & 0.233 & 0.981 & 0.0001 & $0.0044 \mathrm{~L}^{3.384}$ \\
\hline $\begin{array}{l}\text { Esox lucius } \mathrm{L} \text {. } \\
\mathrm{n}=6\end{array}$ & 0.651 & 0.0041 & 3.114 & 0.399 & 0.938 & 0.0015 & $0.0041 \mathrm{~L}^{3.114}$ \\
\hline
\end{tabular}

$\mathrm{n}$ - number of fish; $\mathrm{p}$ - significance levels, FCF - Fulton's condition factor, W - relative condition factor, SE(b) - standard error, a - intercept of the line on $\mathrm{y}, \mathrm{b}$ - slope of the regression line 


\section{Discussion}

In this study, predatory fish displayed a higher content of mercury than non-predatory fish (Table 1). Similar observation was reported by Łuczyńska et al. (15). These results are also consistent with those of Havelková et al. (8) and Svecevičius et al. (22). The highest content of mercury in the muscles of predatory fish (asp, pike, pikeperch) was observed by Kenšová et al. (11), but the differences between pike and bream were insignificant. Máršalek et al. (16) noted the highest content of mercury in the muscles of asp, followed by eel (Anguilla anguilla L.) and bighead carp (Aristichthys nobilis), bream and roach. Benthophagous species (roach) from the Šalek lakes (Slovenia) also contained lower amount of mercury $(0.08 \mathrm{mg} / \mathrm{kg})(1)$. Muscles of roach from the Hamry fresh water reservoir on the Chrudimka River (Czech Republic) accumulated a lower amount of mercury than bream, an omnivorous fish species, and perch (5); in contrast, muscle mercury content in fish from natural water of West Pomerania ranged from 0.01 (bream) to $0.19 \mathrm{mg} / \mathrm{kg}$ (pike) (13). The findings regarding the muscles of pike are in agreement with the results of the present study (Table 1). Andreji et al. (2) observed the highest concentration of this metal in predatory fish (Wels catfish, Silurus glanis L.) from Lower Nitra River and the lowest content in omnivorous fish (Prussian carp, Carassius gibelio L.). According to these authors, there were significant differences in total mercury content among five fish species. The concentration of mercury in the muscles of roach $(0.78 \mathrm{mg} / \mathrm{kg})$ established by these authors was higher than those obtained in our study. Mercury content in whole body of fish from the Vistula Lagoon ecosystem decreased sequentially as follows: roach $=$ Prussian carp $>$ Crucian carp (Carassius carassius L.) > tench (Tinca tinca L.) > European smelt (Osmerus eperlanus L.) > ruffe (Gymnocephalus cernuus L.) > herring (Clupea harengus L.) (18). Noël et al. (20) observed the following sequence: European eel $>$ pikeperch $>$ pike $>$ bream $>$ roach $>$ perch $>$ Common carp (Cyprinus carpio L.) $>$ catfish. On the other hand, Kuklina et al. (12) established the following order: perch $>$ pikeperch $>$ rudd $>$ tench (Tinca tinca L.) $>$ roach $>$ bream.

Previous studies showed that the mercury content in the muscles of pike, perch, and roach from the Lake Pluszne was $0.146-0.367,0.104-0.530$, and 0.100 $0.198 \mathrm{mg} / \mathrm{kg}$, respectively (14). The same authors observed that the amount of mercury increased with rising body weight and length, regardless of the species or their habitat. According to Sakizadeh et al. (21), the positive correlation between total mercury concentration in the muscles of pike and its body weight was significant $(r=0.950, p=0.023)$, whereas the positive relationship between mercury content in muscle tissue of pike and the length of these specimens was insignificant $(r=0.796, p=0.09)$. Correlation coefficient between the length of pike from small boreal lakes (Southern Finland) and mercury content in their muscles was $\mathrm{r}=0.68, \mathrm{p}<0.001$ (23); however, the concentration of mercury in the muscles of perch from the Lake Velenjsko (Slovenia) did not depend on the length of this fish $(\mathrm{r}=0.01)$. Nevertheless, a positive correlation was found in the muscles of roach $(\mathrm{r}=0.51, \mathrm{p}<0.05)(17)$. The relationship between mercury content and the length or weight of pike, perch, and whitefish was investigated by Moreno et al. (19). These authors found a significant positive correlation between these parameters.

Voigt (25) noted that the content of mercury in muscle tissue depended significantly on the length of perch $(\mathrm{r}=0.33, \mathrm{p}=0.05)$. The same author observed a positive correlation between FCF and mercury content in the muscles of perch. Farkas et al. (6) found a negative relationship between mercury concentration in muscle tissue and FCF of bream $(\mathrm{r}=-0.3192$, $\mathrm{p}=0.006$ and $\mathrm{r}=-0.3510, \mathrm{p}=0.01$ respectively). The correlation showed trends opposite to those related to the length of fish $(r=0.8459$ and $0.8123, p<0.0001)$.

In conclusion, our study demonstrated that predatory fish had a higher content of mercury than non-predatory fish, showing that mercury increases with the advance in food chain of the aquatic environment. The mercury content in the muscles of fish did not exceed the maximum acceptable level according to the Commission Regulation (EC) No $629 / 2008$ of 2 July 2008 , which is $1.0 \mathrm{mg} / \mathrm{kg}$ for pike and $0.5 \mathrm{mg} / \mathrm{kg}$, for the rest of the fish examined. Therefore, from consumers' health point of view, no objections can be raised concerning the examined fish species.

Conflict of Interests Statement: The authors declare that there is no conflict of interests regarding the publication of this article.

Financial Disclosure Statement: The study was financed by the Statutory Theme No. 17.610.008-300. Direct Mercury Analyzer Milestone's DMA-80 was financed by the project "Innovations in finfish aquaculture with special references to reproduction" (acronym: InnovaFish), Operational Programme Sustainable Development of the Fisheries Sector and Coastal Fishing Areas 2007-2013".

Animal Rights Statement: None required.

\section{References}

1. Al Sayegh-Petkovšek S., Mazej Grudnik Z., Pokorny B.: Heavy metals and arsenic concentrations in ten fish species from the Šalek lakes (Slovenia): assessment of potential human health risk due to fish consumption. Environ Monit Assess 2012, 184, 2647-2662. DOI:10.1007/s10661-011-2141-4.

2. Andreji J., Stránai I., Massányi P., Valent M.: Accumulation of some metals in muscles of five fish species from lower Nitra River. J Environ Sci Health, Part A 2006, 41, 2607-2622. DOI: 10.1080/10934520600928003. 
3. Boyd R.S.: Heavy metal pollutants and chemical ecology: exploring new frontiers. J Chem Ecol 2010, 36, 46-58.

4. Castro-González M.I., Méndez-Armenta M.: Heavy metals: Implications associated to fish consumption. Environ Toxicol Pharm 2008, 26, 263-271.

5. Červenka R., Bednařik A., Komárek J., Ondračkova M., Jurajda P., Vitek T., Spurný P.: The relationship between the mercury concentration in fish muscles and scales/fins and its significance. Cent Eur J Chem 2011, 9, 1109-1118.

6. Farkas A., Salánki J., Specziár A.: Age- and size-specific patterns of heavy metals in the organs of freshwater fish Abramis brama L. populating a low-contaminated site. Water Res 2003, 37, 959-964.

7. Guallar E., Sanz-Gallardo M.I., van't Veer P., Bode P., Aro A., Gómez-Aracena J., Kark J.D., Riemersma R.A., MartínMoreno J.M., Kok F.J.: Mercury, fish oils, and the risk of myocardial infarction. N Engl J Med 2002, 28, 1747-1754.

8. Havelková M., Dušek L., Némethová D., Poleszczuk G., Svobodová Z.: Comparison of mercury distribution between liver and muscle - a biomonitoring of fish from lightly and heavily contaminated localities. Sensors 2008, 8, 4095-4109.

9. Jezierska B., Witeska M.: Accumulation of metals in fish. The effect of intrinsic factors. Age and size. In: Metal toxicity to fish. Monographs 2001, 42, 95-98.

10. Kehrig H.A., Seixas T.G., Palermo E.A., Baêta A.P., CasteloBranco C.W., Malm O., Moreira I.: The relationships between mercury and selenium in plankton and fish from a tropical food web. Environ Sci Pollut Res 2009, 16, 10-24. DOI: 10.1007/s11356-008-0038-8.

11. Kenšová R., Čelechovská O., Doubravová J., Svobodová Z.: Concentrations of metals in tissues of fish from the Věstonice reservoir. Acta Vet Brno 2010, 79, 335-345.

12. Kuklina I., Kouba A., Buřič M., Horká I., Ďuriš Z., Kozák P.: Accumulation of heavy metals in crayfish and fish from selected Czech reservoirs. Bio Med Res Int 2014, 2014, 1-9. DOI: $10.1155 / 2014 / 306103$.

13. Lidwin-Kaźmierkiewicz M., Pokorska K., Protasowicki M., Rajkowska M., Wechterowicz Z.: Content of selected essential and toxic metals in meat of freshwater fish from West Pomerania, Poland. Pol J Food Nutr Sci 2009, 59, 219-224.

14. Łuczyńska J.: The influence of weight and length on the mercury content in the muscle tissue of fish from four lakes in the Olsztyn Lake District (Poland). Arch Pol Fish 2005, 13, 51-61.
15. Łuczyńska J., Krupowski M.: Mercury content in organs of commercial fish (Poland) - a short report. Pol J Food Nutr Sci 2009, 59, 345-348.

16. Maršálek P., Svobodová Z., Randák T., Švehla J.: Mercury and methylmercury contamination of fish from the Skalka Reservoir: a case study. Acta Vet Brno 2005, 74, 427-434.

17. Mazej Z., Al Sayegh-Petkovšek S., Pokorny B.: Heavy metal concentrations in food chain of Lake Velenjsko jezero, Slovenia: an artificial lake from mining. Arch Environ Contam Toxicol 2010, 58, 998-1007. DOI: 10.1007/s00244-009-9417-5.

18. Misztal-Szkudlińska M., Szefer P., Konieczka P., Namieśnik J.: Biomagnification of mercury in trophic relation of great cormorant (Phalacrocorax carbo) and fish in the Vistula Lagoon, Poland. Environ Monit Assess 2011, 176, 439-449.

19. Moreno C.E., Fjeld E., Deshar M.K., Lydersen E.: Seasonal variation of mercury and $\delta^{15} \mathrm{~N}$ in fish from Lake Heddalsvatn, southern Norway. J Limnol 2015, 74, 21-30.

20. Noël L., Chekri R., Millour S., Merlo M., Leblanc J.C., Gueirin T.: Distribution and relationships of $\mathrm{As}, \mathrm{Cd}, \mathrm{Pb}$ and $\mathrm{Hg}$ in freshwater fish from five French fishing areas. Chemosphere 2013, 90, 1900-1910.

21. Sakizadeh M., Sari A.E., Abdoli A., Bahramifar N., Hashemi S.H.: Determination of polychlorinated biphenyls and total mercury in two fish species (Esox lucius and Carassius auratus) in Anzali Wetland, Iran. Environ Monit Assess 2012, 184, 3231-3237.

22. Svecevičius G., Kazlauskienė N., Kesminas V., Staponkus R., Taujanskis E., Sauliutė G.: Heavy metal accumulation in fishes of different ecological groups from Kairial landfill regional aquatic ecosystem. The $9^{\text {th }}$ International Conference "Environmental Engineering", Vilnius, Lithuania, 2014, pp. 1-7.

23. Syväranta J., Grey J., Jones R.I., Rask M., Salonen M.: Contribution of trophic position to the mercury content of pike (esox lucius) in small boreal lakes. Verth Internat Verein Limnol 2006, 29, 1757-1761.

24. Szulkowska-Wojaczek E., Marek J., Dobicki W., Polechoński R.: Distribution of mercury in the fishes from the Odra River. Zesz Nauk AR Wroc Zoot 1998, 44, 143-154.

25. Voigt H.R.: Concentrations of mercury and cadmium in perch (Perca fluviatilis L.), ruffe (Gymnocephalus cernuus L.), threespined stickleback (Gasterosteus aculaeatus L.) and nine-spined stickleback (Pungitius pungitius L.) from SW Finnish coastal waters. Acta Univ Carolinae Environ 2007, 21, 151-159. 